\title{
Metabolomic Compound of Calostropis Gigantea Root Extract and the Inhibition Effect on Fibrosarcoma Growth and Caspase 3 Expression on Balb/c Mus musculus
}

\author{
$1^{\text {st }}$ Roihatul Mutiah ${ }^{1}, 2^{\text {nd }}$ Maratus Soliha ${ }^{2}, 3^{\text {rd }}$ Elok Kamilah Hayati ${ }^{2}, 4^{\text {th }}$ Retno Susilowati $^{3}$, \\ $5^{\text {th }}$ Rahmi Annisa ${ }^{1}$ \\ \{roiha@farmasi.uin-malang.ac.id ${ }^{1}$ \}
}

\begin{abstract}
Pharmacy Departement Faculty of Medical and Health, Universitas Islam Negeri Maulana Malik Ibrahim Malang, Indonesia ${ }^{1}$, Chemistry Departement Faculty of Sciences and Technology, Universitas Islam Negeri Maulana Malik Ibrahim Malang, Indonesia ${ }^{2}$, Department of Biology Faculty of Sciences and Technology, Universitas Islam Negeri Maulana Malik Ibrahim Malang, Indonesia ${ }^{3}$
\end{abstract}

\begin{abstract}
The root of Calotropis gigantea (thistle) is an Indonesian herb to treat cancer based on empirical and scientific evidences. The study aims to find out the infuence of ethanol extract of thistle root in inhibiting cancer cell growth of Mus musculus fibrosarcoma in vivo and to find out metabolite compounds in the thistle root extract. The effect of cancer cell growth inhibition was tested on Mus musculus inducted with 7.12dimetilbenzene $(\alpha)$ antrasena (DMBA) and dose treatment of 50,100 and $150 \mathrm{mg} / \mathrm{Kg}$ body weight. The metabolomic analysis on the root employs UPLC-QToF-MS/MS as a positive ESI ion source, the movement phase of water/acid mixture is $99.9 / 0.1[\mathrm{v} / \mathrm{v}]$ and acetonitrile/formic acid was 99.9/0.1 [v/v] with gradient elution system and stationary phase of C18. The chromatogram was analyzed using masslynx 4.1. The component identification was based on the $\mathrm{m} / \mathrm{z}$ ratio measured in masslynx and $\mathrm{m} / \mathrm{z}$ counted in chemdraw. The result of the study showed that the thistle root extract use dose of 50, 100 and $150 \mathrm{mg} / \mathrm{Kg}$ body weight were able to increase the weight of fibro sarcoma mice and have a significant influence on caspase-3 expression with cell apoptosis index $24.3 \%$; $13.3 \%$ and $12.3 \%$ respectively. The result of metabolomic analysis showed 14 compounds found in the root extract. Two major compounds were found out: 4Chlorobenzenethiol with the area $32.51 \%$ and $\mathrm{N}$-[1-(Adamantan-1-yl) ethyl]-2-(1piperidinyl)-4-quinazolinamine with the area $37.20 \%$. It was indicated responsible for the anticancer activity of thistle root extract.
\end{abstract}

Keywords: Calotropis gigantea; caspase-3; fibrosarcoma; metabolomic; UPLC-QToFMS/MS

\section{Introduction}

Cancer becomes one of the health problems in the world nowadays. It is a second killer illness in the world after cardiovascular diseases. In Indonesia, it is a fifth killer after cardiovascular, infection, digestion and respiratory diseases. Increasing number of population growth and life expectancy leads to a prediction that in 2030 there will be 27 million cancer cases, 17 millions death per year due to cancer and 75 millions people living with cancer [1]. 
Fibro sarcoma is a cancer on soft tissues. It's usually occurs on 35-55 years old people. It is commonly found on men rather than women. Many people living with this disease end with death. In 2013 US had 11,410 soft tissue cancer cases and they claimed the lives of 4,390 patients [2].

Herbs become an alternative in fibro sarcoma treatment. One of them is Calotropis gigantea (thistle) which can be used for treating several illnesses. Previous research reported that a $95 \%$ alcohol extract of thistle root tested on albino mice indicated an analgesic activity [3]. It also served as contraseptive pill [4]. Some evidences show that it is able to inhibit the growth of gastric cancer cells SGC-7901 in vitro [5]. Methanol extract (ME) and chloroform fraction of thistle root have the ability to inhibit the growth of ascites carcinoma [6]. It is also reported the cytotoxic potency of cardenolide compound of leaves extract on breast cancer cell MCF-7, skin cancer cell KB, lung cancer cell NCL-H18 [7], the cytotoxic potency of dichloromethane extract of the leaves on breast cancer cell MCF-7 and MDA-MB-231, Hela cell, colon cancer cell HT-29, ovarium cancer cell SKOV-3, hepar cancer cell Hep-G2 [8].

It is also reported that acetate ethyl fraction of thistle root is able to inhibit the growth of colon cancer cell WiDr cell line through apoptosis induction and inhibition phase G2/M (9). Some active compounds isolated from C.gigantea root are calotropin (1), frugoside (2), afroside (3) ,15b-hydroxycalotropin (4), 15b-hydroxycalactin (5), calactin (6), calotoxin (7), 16a-hydroxycalactin (8), uscharin (9), coroglaucigenin (10), 4'b,15b-dihydroxycalactin (11), 15b-hydroxyuscharin (12), 5b-hydroxycalac-tinic acid methyl ester (13), calactinic acid ethyl Ester (14), 15b-hydroxycalactinic acid ethyl ester (15) [10]. The study aims to find out the influence of adding ethanol extract of thistle root on the growth inhibition of Mus musculus cancer cell in vivo and find out the content of active compounds influencing anticancer activities.

\section{Experimental}

\subsection{Materials}

Thistle root was determined in LIPI Purwodadi, East Java, Indonesia. Mice (Mus musculus) balb/c, ethanol $70 \%$, aquades, 7,12-Dimetilbenzene( $\alpha$ )antrasena (DMBA), aseton, CMC-Na (carboxymethylcellulose natrium), monoclonal antibody anti-caspase 3 (ABM1C12), methotrexate, alcohol $70 \%$, aquades, wood powder, mice food and water, Chloroform.

\subsection{Ethical Agreement}

The study has been approved by The Ethical Committee of Faculty of Medicine, Brawijaya University, certificate number: 225-KEP-UB, April 24, 2014.

\subsection{Maceration Extraction}

$100 \mathrm{gr}$ of thistle root powder is soaked in $500 \mathrm{ml}$ ethanol solvent $70 \%$ for 24 hours and put into shaker for 3 hours in the beginning of maceration process, and then filtered. The treatment is repeated on the waste to get a clear filtrate. The filtrate extract is concentrated using rotary evaporator and put into oven with $37^{\circ} \mathrm{C}$ temperature to eliminate the solvent residue. Then the concentrated extract is scaled and its rendement is counted.

\subsection{Experimental Animal Treatment}


The experimental animals, 30 male Mus musculus Balb/C 20-30 gr were acclimatized for \pm 5 days, and ad libitum feed. They are put into 5 groups [11]:

a. Negative control group consists of inducted DMBA mice and they are given CMC $\mathrm{Na} 0,5 \% 0,5 \mathrm{~mL}$ without ethanol extract of thistle root treatment.

b. Positive control group is a group of DMBA-induced mice, which is also injected with cancer drugs, ie methotrexate with a dose of $2.5 \mathrm{mg} / \mathrm{kg}$ body weight (BW).

c. Dose 1 group is a group of DMBA-induced mice, which also received therapy of ethanol extract of thistle root with the dose of $50 \mathrm{mg} / \mathrm{Kg} \mathrm{BW}$.

d. Dose 2 group is a group of DMBA-induced mice, which also received therapy of ethanol extract of thistle root with the dose of $100 \mathrm{mg} / \mathrm{Kg} \mathrm{BW}$.

e. Group Dose 3 is a group of DMBA-induced mice, which also received therapy of ethanol extract of thistle root with the dose of $150 \mathrm{mg} / \mathrm{Kg} \mathrm{BW}$.

$0.5 \mathrm{~mL}$ ethanol extract of thistle root was administered orally using naso gastric tube for 14 days.

\subsection{Induction 7.12-dimethylbenz ( $\alpha$ ) anthracene}

DMBA solution with a concentration of $25 \mu \mathrm{g} / 0.1 \mathrm{~mL}$ of acetone was injected subcutaneously at the nape of the mice using $1 \mathrm{ml}$ syringe twice a week, on Tuesday and Friday for 6 weeks. Before induction, each mouse was weighed [12].

\subsection{Taking Out Cancer Tissue [13]}

After the treatment period, the mice was killed through euthanasia method, by inhalation of chloroform. Mice were put into the chamber containing the cotton, which is previously filled with chloroform. Dead mice were placed on the surgical board and their cancer tissue (nodules) were carefully removed. The nodules taken out are white gray pearl tissues like typical fresh fish meat [14]. Nodules were washed with PBS until they are clean from the blood, and they are dried over on a filter paper to prepare a caspase-3 immunohistochemical preparation.

\subsection{Immunohistochemistry caspase 3}

Paraffin slides were undergoing deparaffination, performed in $3 x$ xylene for 3 minutes. Then were rehydrated using ethanol $(100 \%, 95 \%$ and $70 \%)$ and water. Endogenous peroxidase activity was blocked by soaking the sections in peroxidase blocking solution at room temperature for 10 minutes. After incubation in prediluted blocking serum at $25^{\circ} \mathrm{C}$ for 10 minutes, slides then were soaked $\left(25^{\circ} \mathrm{C}, 10\right.$ minutes $)$ in monoclonal antibody anti-caspase 3 (ABM1C12) and were washed using Phospate Buffer Saline (PBS) for 5 minutes. The slides were incubated with secondary antibody, conjugated to horse radish peroxidase, followed by the next incubation using peroxidase. Both incubation were performed at $25^{\circ} \mathrm{C}, 10$ minutes) and washed using PBS for 5 minutes. The slides were then incubated with Hematoxylin Eosin ( 3 minutes) and washed using running water. After mounting media dropping, the slide were covered by coverslip.

\subsection{Measurement of apoptosis index and Allerd scoring}

Expression of Caspase 3 (brown color) were observed using under 400x light microscope. The pictures are captured using a microtome of 10 fields of vision.

The apoptosis index was then determined as a measurement of cell apoptosis level using the equation [15]: 


$$
\text { Apoptosis index (IA) }=\frac{\text { apoptosis cell }}{\text { total cell }} \times 100 \%
$$

In addition, semi quantitative analysis using the Allred scoring method was performed with an assessment on two categories, namely the number or percentage of positive expressed cells and the intensity of the color. The IS score shows an intensity score of 0 (negative or no brown color), 1 (weak brown color), 2 (medium brown) and 3 (strong brown). The IP value indicates the percentage of brown color, which is 0 (no color, $1(\leq 1 / 100$ colorless cell), 2 ( $\leq 1 / 10$ colored cell), 3 ( $\leq 1 / 3$ colored cell), 4 ( $\leq 2 / 3$ colored cells) and 5 (all cells are colored) The sum of IS and IP is the total CPI score [15].

\subsection{Ultra Performance Liquid Chromatography-Quadrupole Time of Flight-Mass Spectrometry (UPLC-QToF-MS) Analysis}

The analysis of UPLC-QToF-MS employed UPLC-MS systems with QToF as the analysator and positive ESI as the ionization source with the Acquity $\mathrm{C} 18$ column $1,8 \mu \mathrm{m} ; 2,1$ $\times 150 \mathrm{~mm}$. The applied eluent was the mixture between (A) water (HPLC grade)/formic acid 99,9/0,1 [v/v]; (B) Asetonitril/formic acid 99,9/0,1 [v/v] and the system of gradient elution. The comparison is presented as in Table 1.

Table 1. The Comparison Of Eluent A And Aluent B

\begin{tabular}{|l|l|l|}
\hline Time (minutes) & \% Eluent A & \% Eluent B \\
\hline 0,00 & 95,0 & 5,0 \\
\hline 2,00 & 75,0 & 25,0 \\
\hline 3,00 & 75,0 & 25,0 \\
\hline 14,00 & 0,0 & 100,0 \\
\hline 15,00 & 0,0 & 100,0 \\
\hline 19,00 & 95,0 & 5,0 \\
\hline 23,00 & 95,0 & 5,0 \\
\hline
\end{tabular}

The source temperature was $100^{\circ} \mathrm{C}$ and the desolvation temperature was $350^{\circ} \mathrm{C}$. A $10 \mathrm{mg}$ extract sample was solved in $10 \mathrm{ml}$ volumetric flask with absolute methanol then it was injected into UPLC-MS system. From chromatogram data, the area was in percentage. The chromatogram was processed using masslynx version 4.1 software. The component identification was based on the ratio of measured $\mathrm{m} / \mathrm{z}$ in masslynx and chemdraw.

\subsection{Data analysis}

Anticancer test data analysis using SPSS program of One Way ANOVA method to determine the significance of the average treatment effect on body weight of mice and caspase-3 CPI score.

\section{Result and Discussion}

The objective of this research was to determine the effect of ethanol extract of the roots of thistle on the inhibition of the growth of fibro sarcoma of animal model of balb/c mice 
induced by DMBA. In addition, this study aimed to analyze the content of metabolites contained in the ethanol extract of the roots of thistle. Fibro sarcoma animal model was used in this study since it has higher percentage of fibro sarcoma incidence and easier induction of in vivo fibro sarcoma in balb/c mice with DMBA carcinogen comparing to other types of cancer animal models. The anticancer inhibitory effect is seen from the growth parameters of mice body weight after undergoing therapy and caspase- 3 expression. Metabolite content was analyzed using UPLCMS method. The ion source used in the UPLCMS is ESI (+) positive with MS Q-TOF analysis.

\subsection{Mice Weight Changes}

Increased body weight of fibro sarcoma mice compared to the control after treatment is one of the indicators of the development of cancer healing. Mice weight change during treatment is shown in Figure 1 and table 2.

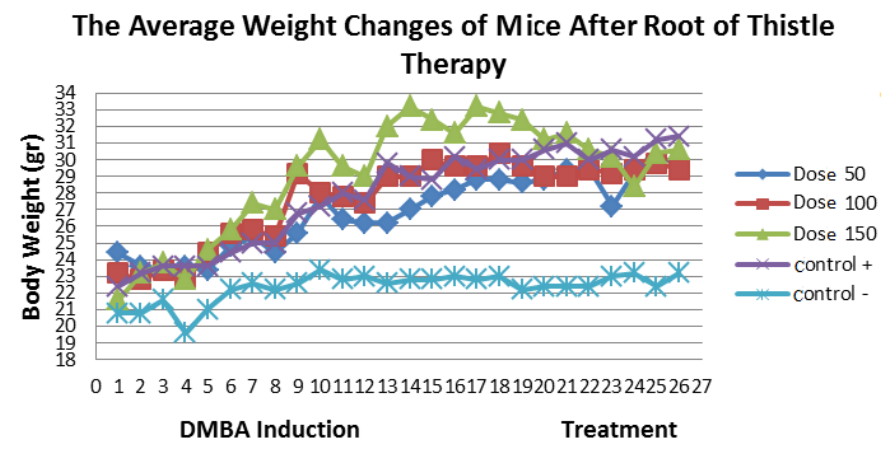

Figure 1. The Graph of the weight changes of mice induced by DMBA $25 \mathrm{mg} / 0.1 \mathrm{ml}$. Induction is performed twice a week for 6 weeks (1-12) and therapy is given for 14 days since day 13 to 26 .

Graph 1 shows that giving ethanol extract of thistle root has an effect on the increasing body weight of mice. Differences in weight gain of fibro sarcoma model mice on the control and statistical analysis results are presented in table 2.

Table 2. Effect Of 70\% Ethanol Extract Of Thistle Root On The Changes In Body Weight Of Fibro Sarcoma Model Mice

\begin{tabular}{|c|c|c|c|}
\hline \multirow[t]{2}{*}{ Group } & \multicolumn{3}{|c|}{$\%$ Increase in Significance (p) } \\
\hline & Weight \pm SD * & $\begin{array}{l}\text { Negative } \\
\text { controls }\end{array}$ & Positive control \\
\hline A dose of $50 \mathrm{mg} / \mathrm{kg} \mathrm{BW}$ & $14.68 \pm 2.98$ & 0.000 & 0.993 \\
\hline A dose of $100 \mathrm{mg} / \mathrm{kg} \mathrm{BW}$ & $7.39 \pm 2.77$ & 0.109 & 0.110 \\
\hline A dose of $150 \mathrm{mg} / \mathrm{kg} \mathrm{BW}$ & $5.60 \pm 3.39$ & 0.371 & 0.025 \\
\hline Positive Control & $13.63 \pm 4.05$ & 0.000 & - \\
\hline Negative Control & $1.13 \pm 5.32$ & - & 0.000 \\
\hline
\end{tabular}

*Average weight gain \pm Standard Deviation (SD), repetition is done 3 times on different experiments.

The largest weight gain rate is owned by the $50 \mathrm{mg} / \mathrm{Kg} \mathrm{BW}$ dose therapy group with an increase of $14.68 \%$. This shows that thistle root extract therapy with dose of $50 \mathrm{mg} / \mathrm{Kg} \mathrm{BW}$ 
has a higher effectiveness to inhibit the growth of cancer cells than other treatments. This number was followed by a positive control group, then a dose of $100 \mathrm{mg} / \mathrm{Kg} \mathrm{BW}$ and $150 \mathrm{mg} /$ Kg BW therapy group.

Tukey test results indicated that treatment group that had significant difference of weight gain $(\mathrm{p}<0.05$ ) with negative control were treatment group of dose of $50 \mathrm{mg} / \mathrm{Kg} \mathrm{BW}$ and positive control group. Meanwhile, the therapy group and the positive control group did not have a significant difference in weight gain because the treatment groups had similar effects on weight gain in mice.

\subsection{Caspase-3 Immunohistochemistry (CPI)}

The observation on the tissue slide was done by using a compound light microscope with 400 times magnification as much as 10 fields of visual. Positive cells expressing caspase-3 will have a brown cytoplasm due to anticaspase- 3 antibody reactions visualized by DAB chromogen. The result of microscopic observation of caspase-3 immunohistochemistry in the treatment group can be seen in Figure 2.

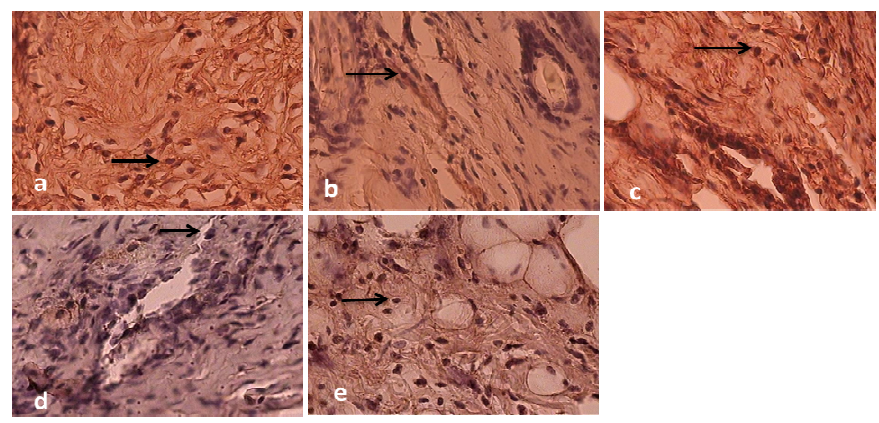

Figure 2. Results of caspase- 3 immunohistochemistry through microscopic observations at $400 \times$ magnification,

a) The expression of caspase-3 (arrow) in the negative control treatment,

b) The expression of caspase-3 (arrow) in the positive control treatment with methotrexate treatment

c) The expression of caspase-3 (arrow) on dose of $50 \mathrm{mg} / \mathrm{Kg} \mathrm{BW}$ treatment

d) The expression of caspase-3 (arrow) on dose of $100 \mathrm{mg} / \mathrm{Kg} \mathrm{BW}$ treatment

e) The expression of caspase-3 (arrow) on dose of $150 \mathrm{mg} / \mathrm{Kg} \mathrm{BW}$ treatment

The cell measurement results that express caspase 3 showed that bigger index apoptosis was shown by mouse from dosage group of $50 \mathrm{mg} / \mathrm{Kg} \mathrm{BW}$ that is $24.3 \%$ followed by positive control group, the group of dosage therapy $100 \mathrm{mg} / \mathrm{Kg} \mathrm{BW}$ and dosage $150 \mathrm{mg} / \mathrm{Kg} \mathrm{BW}$. This result shows that giving extract of thistle root can decrease the growth of cancer cell that is shown with the bigger apoptosis index from mouse of negative control. It is caused by cytotoxic activity from thistle root that can resist cancer cell growth through apoptosis induction [9]. Semi quantitative analysis results that uses Allerd scoring method also shows the higher scores in the therapy group. The result from measurement of apoptosis index and Allerd scoring are presented in Figure 3 and table 3. 


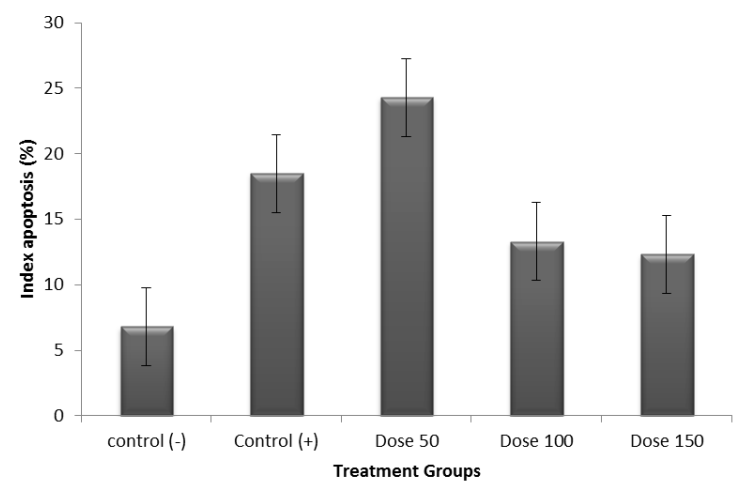

Figure 3. The treatment effect of $70 \%$ ethanol extract of thistle root on apoptosis index of fibro sarcoma model mice

The result of Tukey test shows the experimental group has significant different CPI score of caspase- 3 with negative control is experimental group with dosage of $50 \mathrm{mg} / \mathrm{Kg} \mathrm{BW}$, dosage $100 \mathrm{mg} / \mathrm{Kg} \mathrm{BW}$ and positive control (score $\mathrm{p}<0.05$ ). It shows that extract of thistle root can increase expression of caspase-3 for mice inducted with DMBA. Caspase-3 (cysteineaspartic acid protease) is a protein in code CAPS3 that has important role for the cell apoptosis. In the cell apoptosis process, the activity of caspase- 3 is inducted by caspase- 8 , caspase-9 and caspase 10 [16].

Table 3. The Result Of Apoptosis Index Analysis And Cpi Score Of Caspase-3

\begin{tabular}{|c|c|c|c|c|}
\hline \multirow[t]{2}{*}{ Groups } & \multirow{2}{*}{$\begin{array}{l}\text { Index } \\
\text { apoptosis } \\
\text { (IA) }(\%)\end{array}$} & \multirow{2}{*}{$\begin{array}{l}\text { CPI Score } \\
\text { of } \\
\text { caspase-3 } \\
\pm \text { SD* }^{*}\end{array}$} & \multicolumn{2}{|c|}{ Significance (p) } \\
\hline & & & $\begin{array}{l}\text { Negative } \\
\text { Control }\end{array}$ & $\begin{array}{l}\text { Positive } \\
\text { Control }\end{array}$ \\
\hline Dosage $50 \mathrm{mg} / \mathrm{Kg} \mathrm{BW}$ & 24.3 & $\begin{array}{l}6.00 \\
0.82\end{array}$ & 0.000 & 0.138 \\
\hline Dosage $100 \mathrm{mg} / \mathrm{Kg} \mathrm{BW}$ & 13.3 & $\begin{array}{l}4.90 \\
0.74\end{array}$ & 0.003 & 0.897 \\
\hline Dosage $150 \mathrm{mg} / \mathrm{Kg} \mathrm{BW}$ & 12.3 & $\begin{array}{l}4.40 \\
0.69\end{array}$ & 0.138 & 0.138 \\
\hline Positive Control & 18.5 & $\begin{array}{l}5.20 \\
0.79\end{array}$ & 0.000 & - \\
\hline Negative Control & 6.8 & $\begin{array}{l}3.60 \\
0.69\end{array}$ & - & 0.000 \\
\hline
\end{tabular}

*average caspase-3 expression \pm Standard Deviation (SD), repetitions are done three times in the different experiment.

The result of caspase- 3 score is equal with the apoptosis index and mice's weight gain where the higher the score of caspase- 3 and apoptosis index, the higher the mice's weight gain during therapy. From the three therapy groups, the group of dosage $50 \mathrm{mg} / \mathrm{Kg} \mathrm{BW}$ has capability in gaining highest expression of caspase- 3 followed by positive control group. It shows that the giving of extract of thistle root in that dosage has higher cytotoxic effectiveness compared to that is given by Methotrexate medicine. Meanwhile, mice of therapy group of dosage 100 and $150 \mathrm{mg} / \mathrm{Kg} \mathrm{BW}$ also have higher CPI score than negative control group even the score is lower than positive control group's. It is caused by mice's immunity in the certain dosage. 


\subsection{The Analysis of Metabolomics using UPLCMS/MS Method}

The objective of metabolomics analysis is to determine the secondary metabolic compound in ethanol extract of thistle root. UPLC-MS is a method in analyzing metabolic profile that offers resolution, speed, and high sensitivity, even widely able to be used in pharmaceutical analysis, such as fatty acid long chain, underivatized amino acid and opiates in many kinds of matrix [17]. MS Detector with ESI ion source (+) and MS analyzer in Q-ToF UPLC-MS is specification of UPLCMS/MS tool that is used in this research. UPLCMS/MS chromatogram of ethanol extract of thistle root is presented in figure 5 .

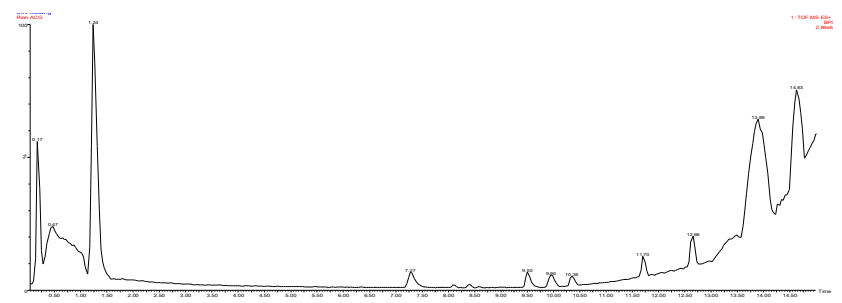

Obtained chromatogram is then processed using masslynx software version 4.1. The program of this software will help to obtain $\mathrm{m} / \mathrm{z}$ spectra data and molecular formula. Prediction of this molecular formula will find the name of the compound by assistant of Chemspider website. When writing the molecular formula in this website, the number of $\mathrm{H}$ molecule will be decreased by 1 . It is caused by positive ESI ion source will add $\mathrm{H}$ content to the intended compound, so that the number of its $\mathrm{m} / \mathrm{z}$ must also be decreased from $\mathrm{H}$ atom's real mass, that is 1.0078 . After obtaining the name of the compound and its structure from that website, then compare the $\mathrm{m} / \mathrm{z}$ measured to $\mathrm{m} / \mathrm{z}$ calculated by drawing related compound structure in the Chemdraw Ultra 12.0 application [18] [19]. If the difference of them is $\leq 0.0005$, then it can be said that this tip has predicted compound [20]. Component identification is based on the comparison of $\mathrm{m} / \mathrm{z}$ measured in Masslynx and $\mathrm{m} / \mathrm{z}$ calculated in chemdraw. The analysis using UPLCMS/MS obtains 14 chemical compounds consist of two compounds with widest area (width of $37.20 \%$ and $32.52 \%$ ), five compounds' structures are not yet found, and seven compounds with width of $(0.15 \%-3.19 \%)$. Spectra $\mathrm{m} / \mathrm{z}$ of mayor compound is presented in figure 4 and 5.

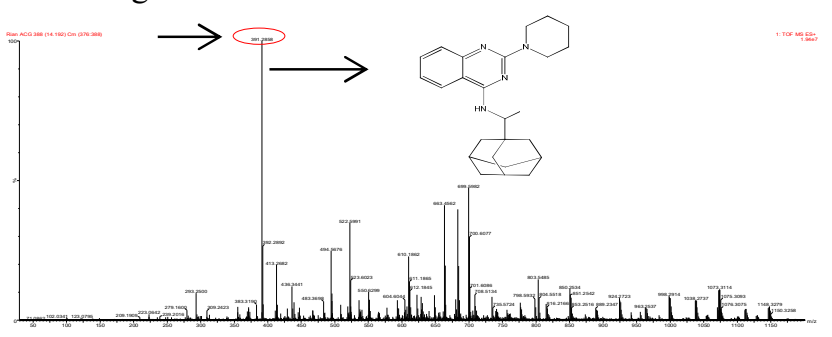

Figure 4. Spectra of $\mathrm{m} / \mathrm{z}$ mass first mayor compound N-[1-(Adamantan-1-yl) ethyl]-2-(1-piperidinyl)-4quinazolinamine 


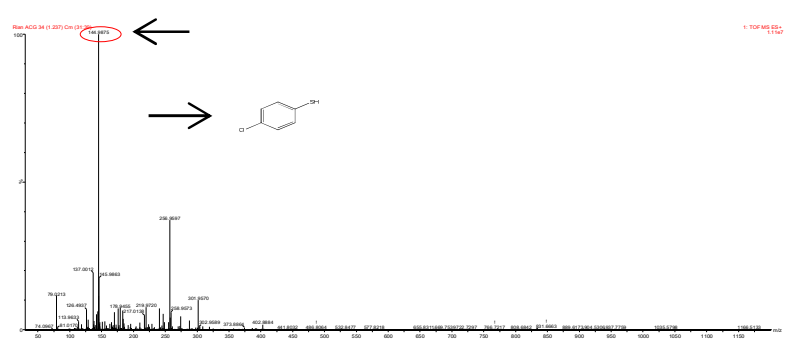

Figure 5. Spectra of $\mathrm{m} / \mathrm{z}$ mass second mayor compound 4-Chlorobenzenethiol

\section{Conclusion}

The giving of ethanol extract $70 \%$ root of Calotropis gigantea (thistle) in doses of 50, 100 and $150 \mathrm{mg} / \mathrm{Kg} \mathrm{BW}$ for the fibro sarcoma model mice causes apoptosis induction for cancer cell through the increasing of caspase-3 expression with cell apoptosis index of $24.3 \%$; $13.3 \%$ and $12.3 \%$. The analysis using UPLCMS/MS obtains 14 chemical compounds with two mayor compounds, they are 4-Chlorobenzenethiol with area percentage of $32.51 \%$ and $\mathrm{N}$ [1-(Adamantan-1-yl) ethyl]-2-(1-piperidinyl)-4-quinazolinamine compound with area percentage of $37.20 \%$.

Acknowledgements. The researcher would like to express highest gratitude to Directorate General of Islamic Higher Education of Republic of Indonesia for the funding support given to the grant schema of Collaborative Research in 2017. This paper in conjuction with the 1st International Conference On Islam, Science, And Technology (ICONIST) 2018, Malang, East Java

\section{References}

[1] WHO (World Health Organization). World Health Statistic 2013. (2014) available at http://who.int/gho/publications.

[2] ACS (American Cancer Society). Cancer Fact \& Figure 2013. (2013). Available at http://cancer.org/research.

[3] Argal A and Pathak AK. "CNS Activity of Calotropis gigantea Roots". Journal of Ethnopharmacology, Vol 106, pp.142-145, 2006

[4] Srivastava SR, Keshri G, Bhargavan B, Singh C, Singh MM. "Pregnancy Interceptive Activity of the Roots of Calotropis gigantea Linn in Rats". Contraception. Vol. 75, pp.318- 322, 2007

[5] Wang ZN, Wang MY, Mei WL, Han Z and Dai HF. "A New Cytotoxic Pregnanone from Calotropis gigantea”. Molecules. Vol.13, pp. 3033-3039. 2008

[6] Habib MR and Karim MR. "Evaluation of antitumour activity of Calotropis gigantea L. root bark against Ehrlich ascites carcinoma in Swiss albino mice". Asian Pacific journal of tropical medicine. Vol. 4, pp.786-90. 2011

[7] Seeka C and Sutthivaiyakit S. "Cytotoxic cardenolides from the leaves of Calotropis gigantea”.Chemical \& pharmaceutical bulletin. Vol. 58, pp. 725-8. 2010

[8] Wong SK, Lim YY, Abdullah NR and Nordin FJ. "Assessment of antiproliferative and antiplasmodial activities of five selected Apocynaceae species". BMC complementary and alternative medicine. vol 11 issue 3. 2011 
[9] Mutiah R, Widyawaruyanti A, Sukardiman S., :Ethyl acetate fraction of Calotropis gigantea roots induce apoptosis through increased G2/M and increased expression of caspase- 8 in colon cancer WiDr cell line.” J App Pharm Sci. vol.7, pp.197-201. 2017

[10] You H, Lei M, Song W, Chen H, Meng Y, Guo D, Liu X. Cytotoxic cardenolides from the root bark of Calotropis gigantea. Steroids. Vol. 78, pp. 1029-1034, 2013

[11] Habib MR, Aziz MA and Karim MR. "Inhibition of Ehrlich ascites Carcinoma by Ethyl Acetate Extract from The Flower of Calotropis gigantea L. in Mice". J. Appl Biomed vol. 8, pp.4754,2010

[12] Manoharan S, Mookkan M and Nagarethinam B., "Chemopreventive Efficacy of Berberine in 7,12-dimetthylbenz $(\alpha)$ anthracena (DMBA) Induced Skin Carcinogenesis in Swiss Albino Mice", $J$. Res. Pharm. Sci. vol 1, pp. 521-529. 2010

[13] Kumar SS, Rao MRK and Balasubramanian MP. "Antiproliferative role of Indigofera aspalathoides on 20 methylcholanthrene induced fibrosarcoma in rats." Asian Pasific Journal of Tropical Medicine. Vol. 1, pp. 966-974. 2012

[14] Robbins and Kumar. Buku Ajar Patologi 1. Edisi 4. Jakarta. EGC. (). Pp. 290- 293. 1995 [Text In Indonesia]

[15] Allerd DC, Harvey JM, Berardo M and Clark GM. "Prognostic and Predictive Factors in Breast Cancer by Immunohistochemical Analysis". Mod Pahol, vol.11, pp. 155-168. 1998

[16] Elmore S. Apoptosis: “A Review of Programmed Cell Death.” Toxicol Pathol. Vol. 35, pp.495-516. 2007

[17] Hampel D, York ER and Allen LH. "UPLC-MS for the Rapid, Simultaneous Analysis Of Thiamin, Roboflavin, Flavin Adenine Dinucleotide, Nicotinamide and Pyridoxal in Human Milk". Journal of Chromatography B. vol. 903, pp.7-13. 2012

[18] Skoog DA, West DM, Holler FJ, Crouch SR. Fundamentals of Analytical Chemistry. Eighth Edition. Belmont, CA: Thomson Brooks/Cole. Pp: 112-113. 2004)

[19] Caundhary DV, UPLC-MS/MS "Methode for different types of category drugs. Fisrts Edition". Create Space Independent Publishing Platform ; 80-85. 2015

[20] Brenton AG, Godfrey AR. "Accurate Mass Measurement: Terminology and Treatment of Dat”a. J. Am. Soc. Mass. Spectrom. Vol 21. pp. 1821-1835. 2010 